\title{
PENGARUH PEMBELAJARAN MATEMATIKA DISKRIT DENGAN BLENDED LEARNING TERHADAP HASIL BELAJAR
}

\author{
Siti Aminah \\ Sekolah Teknik Informatika \& Komputer Indonesia, Malang \\ sitiaminah@stiki.ac.id
}

\begin{abstract}
ABSTRAK
Matematika Diskrit adalah mata kuliah wajib yang ditempuh oleh mahasiswa Teknik Informatika STIKI pada semester pertama. Namun, pembelajaran Matematika Diskrit yang sudah pernah dilakukan, kurang maksimal dalam penggunaan LMS. Penggunaan model pembelajaran yang tepat pada mata kuliah Matematika Diskrit dapat meningkatkan hasil belajar mahasiswa. Selain itu, selalu ada mahasiswa yang hadir tidak konsisten di setiap pertemuan. Akibatnya hasil belajar mahasiswa tidak baik. Artinya bahwa nilai akhir mahasiswa banyak yang mendapatkan nilai $\mathrm{C}$ atau kurang dari $\mathrm{C}$. Oleh karena itu, dibutuhkan model sistem pembelajaran blended pada mata kuliah Matematika Diskrit yang dapat meningkatkan hasil belajar mahasiswa. Tujuan dari penelitian ini adalah untuk melihat pengaruh pembelajaran blended terhadap hasil belajar mahasiswa. Penelitian ini adalah penelitian eksperimen One-Group Pre-Test Post-Test Design. Setelah dilakukan uji coba terhadap model sistem pembelajaran blended Matematika Diskrit, terjadi perbedaan terhadap hasil belajar setelah dilakukan pembelajaran blended. Dengan kata lain, pembelajaran blended berpengaruh signifikan terhadap hasil belajar pada tingkat kepercayaan 95\%. Model sistem pembelajaran blended matematika diskrit dikatakan valid dengan nilai 3,58. Model sistem pembelajaran blended matematika diskrit dikatakan praktis dengan nilai 3. Model sistem pembelajaran blended matematika diskrit dikatakan hampir efektif bagi mahasiswa dengan nilai rata-rata 2.9 dari seluruh indikator.
\end{abstract}

Kata kunci: hasil belajar, matematika diskrit, pembelajaran blended.

\begin{abstract}
Discrete mathematic is compulsory courses which taken by students of informatics engineering in STIKI Malang. But, teacher less than optimal in learning of discrete mathematics with learning management system (LMS). If teacher use appropriate learning model will improve learning outcomes. Another that, student attendance doesn't consistent. So, learning outcome doesn't good. Therefore, teacher need learning model that can improve learning outcome. The aim of this research is known influence blended learning to learning outcome. This research is experiment with One-Group Pre-Test Post-Test Design. After trial blended learning, there is a difference for learning outcome after blended learning. Its means that blended learning significant influence for leaning outcome with level of confident $95 \%$. Blended learning in mathematic discrete course is valid with score 3.58. Blended learning in mathematic discrete course is practice with score 3. Blended learning in mathematic discrete course is enough effective for student with score 2.95 of all indicator.
\end{abstract}

Keywords: learning outcome, discrete mathematic, blended learning.

\section{PENDAHULUAN}

Matematika Diskrit adalah mata kuliah wajib yang ditempuh oleh mahasiswa Teknik Informatika STIKI pada semester pertama. Mata kuliah ini dianggap tidak mendukung untuk menjadi programmer menurut mahasiswa. 
Selain itu, mata kuliah ini dianggap mata kuliah yang sulit karena membutuhkan perhitungan yang rumit. Sehingga dosen perlu memotivasi mahasiswa bahwa mata kuliah ini sangat mendukung pengetahuan mereka di bidang Teknik Informatika. Salah satu cara memotivasi dengan mengkaitkan penerapan materi Matematika Diskrit dengan kehidupan sehari-hari dan menentukan model pembelajaran matematika yang cocok untuk kelas Teknik Informatika ini.

Pembelajaran Matematika Diskrit dilakukan dengan bertatap muka di kelas setiap satu minggu sekali. Metode pembelajaran yang sering dilakukan adalah berceramah dan cooperative learning di setiap pertemuannya. Selain itu, di STIKI, pembelajaran didukung dengan Learning Management System (LMS), yang sering disebut ebelajar dan mudah diakses mahasiswa di ebelajar.stiki.ac.id. Pembelajaran Matematika Diskrit yang sudah pernah dilakukan kurang maksimal dalam penggunaan ebelajar. Fungsi ebelajar pada mata kuliah ini, hanya sebagai tempat upload materi oleh dosen, yang biasanya hanya berupa powerpoint. Materi dalam powerpoint ini adalah sumber belajar mahasiswa di dalam kelas saat dosen berceramah.

Faktanya, selalu terjadi di setiap pertemuan ada mahasiswa dalam kelas ini yang tidak hadir secara konsisten. Akibatnya mereka ketinggalan materi. Sehingga dia harus belajar sendiri dengan melihat powerpoint yang tersedia di ebelajar. Dengan belajar melalui powerpoint, mahasiswa pasti kesulitan memahami isi materi tersebut karena disana tidak tersedia materi yang detail. Jika dosen memilih untuk melakukan pembelajaran dengan metode cooperative learning, mahasiswa yang tidak hadir tidak dapat belajar melalui ebelajar karena tidak akan tersedia materi di ebelajar. Fakta-fakta tersebut diduga menjadi penyebab banyaknya hasil belajar mahasiswa rendah.

Masalah yang dihadapi disini adalah kurang optimalnya dosen dalam menggunakan ebelajar. Meskipun dosen telah memilih metode pembelajaran yang cocok untuk kelas tersebut. Oleh karena itu, dibutuhkan ebelajar yang bisa mengarahkan mahasiswa melakukan aktifitas pembelajaran sesuai dengan prinsip belajar mandiri secara online. Namun, karena matematika membutuhkan penerapan dalam perhitungan, selain pembelajaran online, dosen juga melakukan 
perkuliahan di dalam kelas. Pembelajaran seperti ini sering disebut dengan pembelajaran blended.

Pembelajaran blended adalah sistem pembelajaran yang mengkombinasikan pembelajaran asinkronus dan sinkronus sehingga terbentuknya pengalaman belajar untuk mencapai tujuan pembelajaran yang telah ditentukan (Chaeruman :2017,11). Pembelajaran blended learning memiliki kelebihan dan kelemahan. Kelebihan blended learning menurut (Rusman, Kurniawan, \& Riyana :2013, 271-275) adalah (1) memungkinkan setiap mahasiswa belajar tanpa dibatasi ruang dan waktu, karena akses tersedia kapan saja dan dimana saja; (2) biaya operasional setiap mahasiswa untuk mengikuti kegiatan pembelajaran menjadi lebih terjangkau; (3) pengawasan terhadap perkembangan mahasiswa jadi lebih mudah; (4) rancangan pembelajaran blended learning memungkinkan dilakukannya kegiatan pembelajaran yang sudah terpersonalisasi; (5) materi pembelajaran bisa diperbaharui dengan mudah. Namun, pembelajaran blended learning juga mempunyai kekurangan, yaitu: (1) keberhasilan pembelajaran blended learning bergantung pada kemampuan dan motivasi setiap mahasiswa; (2) akses untuk mengikuti pembelajaran blended learning seringkali menjadi masalah bagi mahasiswa; (3) mahasiswa cepat merasa bosan dan jenuh jika mereka tidak mengakses informasi, dikarenakan tidak terdapatnya peralatan yang memadai dan bandwith yang cukup; (4) kurangnya interaksi langsung antara dosen dan mahasiswa. Blended learning sebagai alternatif sistem pembelajaran yang menerapkan teknologi dalam pembelajaran. Dengan blended learning, media pembelajaran dapat menggunakan multimedia, lebih banyak mengarahkan mahasiwa membaca seperti prinsip belajar mandiri, bisa memilih dan menentukan teknologi pembelajaran sinkron dan asinkron yang relevan dengan tujuan dan strategi pembelajaran, dan dapat menentukan evaluasi sesuai dengan indikator yang telah ditentukan.

Dengan tersedianya semua kegiatan pembelajaran (instruksi pembelajaran, materi, tugas, dan lain-lain) dalam ebelajar, maka materi yang disampaikan di kelas dapat dipahami oleh semua mahasiswa walaupun ada mahasiswa yang tidak bisa mengikuti perkuliahan di setiap pertemuan. Sehingga dampaknya hasil belajar mahasiswa lebih baik dari sebelumnya. Pembelajaran dengan online dapat 
meningkatkan hasil belajar ataupun prestasi siswa (Pathoni dan Aminoto, 2014), (Arnesi dan Hamid, 2015), dan (Santoso, 2009).

Penyusunan pembelajaran blended mengacu pada panduan merancang mata kuliah daring SPADA Indonesia. Penyusunan pembelajaran blended pada Matematika Diskrit menggunakan model desain sistem pembelajaran blended PEDATI yang dibuat oleh Uwes Anis Chaeruman. PEDATI adalah pembelajaran blended pada perguruan tinggi. Siklus alur pembelajaran PEDATI adalah pelajari, dalami, terapkan dan evaluasi. Terdapat 5 langkah yang harus dilakukan dalam PEDATI, yaitu: (1) merumuskan capaian pembelajaran, (2) memetakan dan mengorganisasi materi pembelajaran, (3) memilih dan menentukan aktifitas pembelajaran sinkronus dan asinkronus, (4) Merancang aktifitas pembelajaran asinkronus, (5) Merancang aktifitas pembelajaran sinkronus (Chaeruman: 2017, 16). Hasil luaran dari semua tahapan ini adalah rancangan pembelajaran blended pada mata kuliah Matematika Diskrit. Rancangan ini diterapkan pada ebelajar.stiki.ac.id, yang selanjutnya digunakan sumber belajar mahasiswa yang mengikuti mata kuliah Matematika Diskrit.

Model sistem pembelajaran blended Matematika Diskrit dalam ebelajar ini diujicobakan pada mahasiswa semester genap 2017/2018. Dengan model ini, diharapkan hasil belajar mahasiswa mengalami peningkatan. Tujuan dari penelitian ini adalah untuk melihat apakah model sistem pembelajaran blended matematika diskrit sudah valid, efektif dan praktis untuk digunakan dalam pembelajaran. Tujuan kedua penelitian ini adalah untuk melihat apakah model sistem pembelajaran blended matematika diskrit berpengaruh terhadap hasil belajar mahasiswa.

\section{METODE PENELITIAN}

Penelitian ini adalah penelitian eksperimen One-Group Pre-Test Post-Test Design. Penelitian ini hanya menggunakan satu kelas sebagai kelas uji coba, namun pada satu kelas tersebut diberikan pretest sebelum diberikan pembelajaran blended dan posttest setelah diberikan pembejaran blended. Sehingga besarnya pengaruh pembelajaran blended dapat dilihat melalui nilai pretest dan posttest 
yang diolah menggunakan uji statistika. Penelitian ini dirancang pada Tabel 1 sebagai berikut:

Tabel 1. Rancangan Penelitian Eksperimen

\begin{tabular}{lll}
\hline O1 & $\mathrm{X}$ & $\mathrm{O} 2$ \\
\hline Pretest & $\begin{array}{l}\text { Pembelajaran } \\
\text { blended }\end{array}$ & Posttest \\
\hline
\end{tabular}

Populasi penelitian ini adalah mahasiswa yang mengikuti mata kuliah Matematika Diskrit semester ganjil 2017/2018 di program Studi Teknik Informatika STIKI Malang. Populasi penelitian sebanyak 128 orang. Sampel yang diambil pada penelitian ini adalah 41 orang. Sampel tersebut adalah kelas Matematika Diskrit kelas A pada semester Ganjil 2017/2018. Pengambilan sampel pada penelitian ini menggunakan simple random sampling.

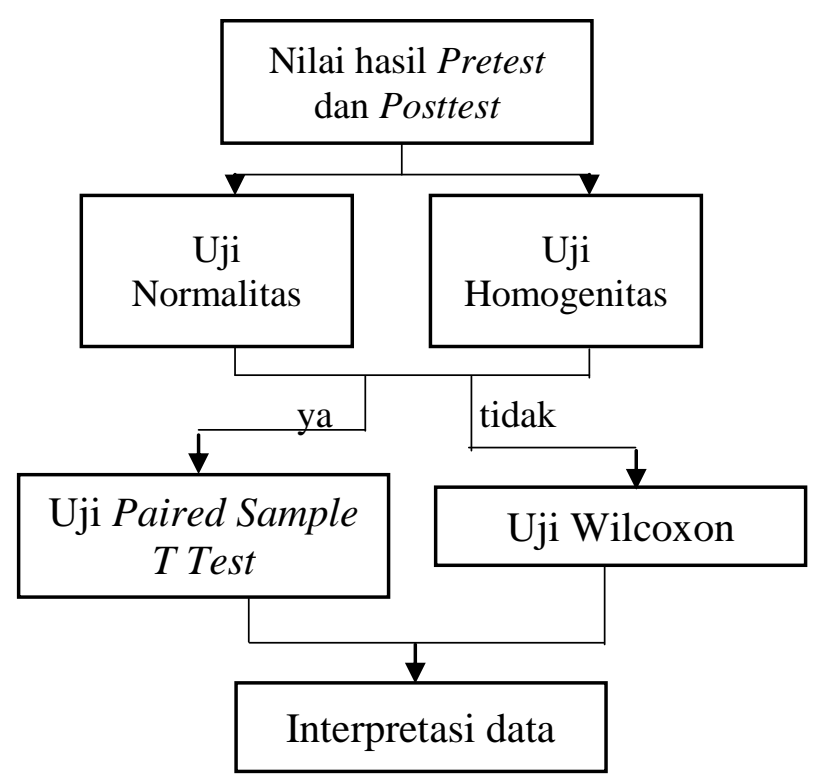

Gambar 1. Prosedur Analisa Data

Instrumen yang digunakan untuk pretest berupa soal berbentuk pilihan ganda yang dapat diakses oleh mahasiswa secara online di LMS STIKI. Sedangkan instrumen yang digunakan untuk posttest berbentuk soal uraian melalui tes tulis. Analisadata menggunakan hasil akhir dari pretest dan posttest. Menurut Prasetyo (2012), dari kedua hasil tes tersebut, dilakukan uji normalitas dan uji homogenitas. Jika hasil pengolahan data normal dan homogen, maka 
dilakukan Uji Paired Sample T Test. Namun, jika hasil pengolahan data tidak normal atau tidak homogen, maka dilakukan uji Wilcoxon. Pengolahan data ini menggunakan SPSS 16.0. Prosedur pengolahan data disajikan dalam Gambar 1.

Sedangkan untuk perhitungan lembar validasi, angket mahasiswa dan dosen menggunakan perhitungan rata-rata. Langkah perhitungan rata-rata dimodifikasi dari Parta (2009) adalah sebagai berikut. (1) Rekap skor dari seluruh item untuk setiap responden, (2) Hitung skor rata-rata untuk setiap responden, (3) Hitung skor rata-rata untuk seluruh responden, (4) penentuan kriteria.

Instrumen yang digunakan untuk melihat kevalidan menggunakan lembar validasi yang diberikan kepada orang yang berkompeten di bidang matematika. Indikator ini disusun berdasarkan panduan pembelajaran daring menurut Chaeruman (2017) yang disesuaikan dengan pembelajaran matematika.

Tabel 2. Indikator untuk melihat kevalidan model sistem pembelajaran hle.nded matematika diskrit

\begin{tabular}{|c|c|}
\hline No. & Aspek yang dinilai \\
\hline \multirow[t]{7}{*}{1.} & $\begin{array}{l}\text { Isi media pembelajaran Matematika Diskrit materi graph menggunakan } \\
\text { moda daring }\end{array}$ \\
\hline & a. Tujuan pembelajaran dinyatakan secara jelas. \\
\hline & b. Petunjuk penggunaan dinyatakan secara jelas. \\
\hline & c. Aktivitas mahasiswa untuk melakukan pengamatan mudah dipahami. \\
\hline & $\begin{array}{l}\text { d. Aktivitas mahasiswa untuk mengilustrasikan soal kedalam bentuk } \\
\text { matematika dinyatakan secara jelas. }\end{array}$ \\
\hline & $\begin{array}{l}\text { e. Aktivitas mahasiswa untuk bertukar pendapat dengan kelompok } \\
\text { diarahkan dengan jelas. }\end{array}$ \\
\hline & $\begin{array}{l}\text { f. Aktivitas mahasiswa untuk menyimpulkan dan menuliskan cara } \\
\text { menyelesaikan masalah diarahkan secara rinci. }\end{array}$ \\
\hline \multirow[t]{5}{*}{2.} & Bahasa, Tulisan, dan Tampilan \\
\hline & a. Kalimat yang digunakan mudah dipahami oleh mahasiswa. \\
\hline & b. Bahasa yang digunakan jelas sehingga tidak menimbulkan makna ganda. \\
\hline & c. Istilah/simbol yang digunakan mudah dipahami oleh mahasiswa. \\
\hline & $\begin{array}{l}\text { d. Tampilan warna, ukuran huruf, dan gambar yang digunakan menarik dan } \\
\text { jelas terbaca sehingga mudah dipahami oleh mahasiswa. }\end{array}$ \\
\hline \multirow[t]{3}{*}{3.} & Manfaat \\
\hline & $\begin{array}{l}\text { a. Media pembelajaran dapat memfasilitasi mahasiswa dalam pembelajaran } \\
\text { untuk memahami materi yang dipelajari. }\end{array}$ \\
\hline & $\begin{array}{l}\text { b. Siswa dapat lebih aktif dalam mengkomunikasikan idenya setelah } \\
\text { belajar dengan menggunakan media pembelajaran Matematika Diskrit } \\
\text { materi graph menggunakan moda daring. }\end{array}$ \\
\hline
\end{tabular}

Untuk melihat keefektifan model sistem pembelajaran blended matematika diskrit menggunakan instrument berupa angket yang diberikan kepada mahasiswa. 
Instrumen ini adalah modifikasi dari Ghavifekr (2015). Berikut ini adalah indikator yang digunakan untuk melihat keefektin model sistem pembelajaran blended matematika diskrit.

Tabel 3. Indikator untuk melihat keefektifan model sistem pembelajaran blended matematika diskit

\begin{tabular}{cl}
\hline NO & \multicolumn{1}{c}{ Indikator } \\
\hline 1 & $\begin{array}{l}\text { Pembelajaran graph pada ebelajar.stiki.ac.id memungkinkan } \\
\text { saya untuk lebih kreatif dan imajinatif. }\end{array}$ \\
\hline 2 & $\begin{array}{l}\text { Pembelajaran graph pada ebelajar.stiki.ac.id membantu saya } \\
\text { untuk menemukan kaitan antara pengetahuan dan informasi } \\
\text { untuk belajar. }\end{array}$ \\
\hline 3 & $\begin{array}{l}\text { Pembelajaran graph pada ebelajar.stiki.ac.id mendorong siswa } \\
\text { untuk aktif mengemukakan pendapat saya di forum diskusi }\end{array}$ \\
\hline 4 & $\begin{array}{l}\text { Pembelajaran graph pada ebelajar.stiki.ac.id membuat saya aktif } \\
\text { saat tatap muka di kelas maupun saat kuliah online }\end{array}$ \\
\hline 5 & $\begin{array}{l}\text { Pembelajaran graph pada ebelajar.stiki.ac.id membuat belajar } \\
\text { saya lebih efektif }\end{array}$ \\
\hline 6 & $\begin{array}{l}\text { Pembelajaran graph pada ebelajar.stiki.ac.id membantu } \\
\text { memperluas kemampuan saya dalam memahami pengetahuan }\end{array}$ \\
\hline 7 & $\begin{array}{l}\text { Pembelajaran graph pada ebelajar.stiki.ac.id membantu } \\
\text { meningkatkan kemampuan saya dalam membaca, menghitung, } \\
\text { memahami materi. }\end{array}$ \\
\hline 8 & $\begin{array}{l}\text { Pembelajaran graph pada ebelajar.stiki.ac.id membantu perilaku } \\
\text { belajar saya lebih baik }\end{array}$ \\
\hline 9 & $\begin{array}{l}\text { Pembelajaran graph pada ebelajar.stiki.ac.id memungkinkan } \\
\text { saya mengekspresikan ide dan pemikiran yang lebih baik. }\end{array}$ \\
\hline 10 & $\begin{array}{l}\text { Pembelajaran graph pada ebelajar.stiki.ac.id mendorong saya } \\
\text { tertarik belajar sehingga pembelajaran seperti ini adalah } \\
\text { pengalaman belajar terbaik saya }\end{array}$ \\
\hline
\end{tabular}

Untuk melihat kepraktisan sistem pembelajaran blended matematika diskrit, menggunakan instrument berupa angket yang diberikan kepada dosen pengampu. Berikut ini adalah indikator untuk melihat tingkat kepraktisan model sistem pembelajaran blended matematika diskrit.

Tabel 4. Indikator untuk melihat kepraktisan model sistem pembelajaran blended matematika diskit

\begin{tabular}{cl}
\hline NO & \multicolumn{1}{c}{ Indikator } \\
\hline 1 & $\begin{array}{l}\text { Setiap aktifitas pembelajaran dapat dilakukan dengan baik dan } \\
\text { tepat waktu }\end{array}$ \\
\hline 2 & $\begin{array}{l}\text { Dengan pembelajaran daring, mahasiswa lebih mudah diamati } \\
\text { dan dikontrol }\end{array}$ \\
\hline 3 & $\begin{array}{l}\text { Dengan pembelajaran daring, lebih mudah mengoreksi tugas } \\
\text { mahasiswa }\end{array}$ \\
\hline 4 & $\begin{array}{l}\text { Dengan pembelajaran daring, lebih mudah mengamati } \\
\text { mahasiswa yang aktif berpendapat dalam forum diskusi }\end{array}$ \\
\hline 5 & Dengan pembelajaran daring, dapat melihat seberapa dalam \\
\hline
\end{tabular}




\begin{tabular}{cl}
\hline NO & Indikator \\
\hline & pemahaman mahasiswa pada materi graph \\
\hline 6 & Bahasa dalam e-belajar mudah dipahami \\
\hline
\end{tabular}

\section{HASIL PENELITIAN DAN PEMBAHASAN}

Dari hasil nilai pretest dan posttest yang diperoleh, dilakukan uji kenormalan menggunakan Kolmogrov Smirnov. Hasil uji Kolmogrov Smirnov terdapat pada Gambar 2 berikut ini.

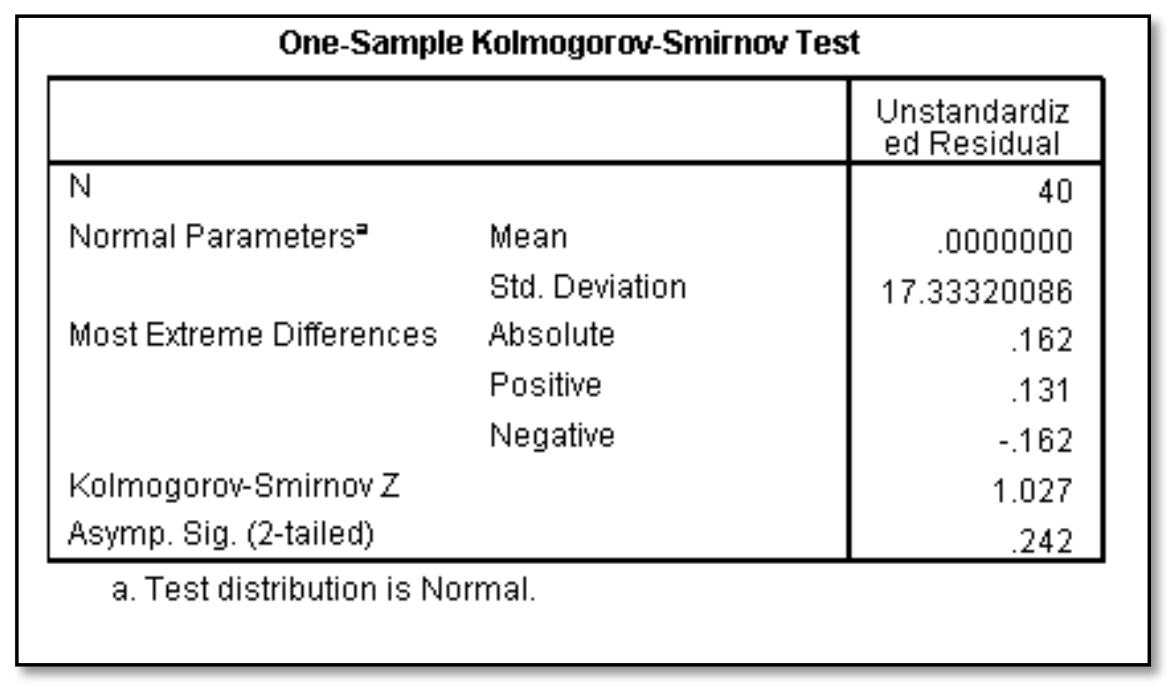

Gambar 2. Hasil Uji Kenormalan

Pernyataan $\mathrm{H}_{0}$, data berdistribusi tidak normal. Pernyataan $\mathrm{H}_{1}$, data berdistribusi normal. level of significance $(\alpha)$ pada uji kenormalan ini adalah 5\%. Dasar pengambilan keputusan adalah tolak $\mathrm{H}_{0}$ jika nilai probabilitas $(\mathrm{Sig})>5 \%$ dan terima $\mathrm{H}_{0}$ jika nilai probabilitas $(\mathrm{Sig})<5 \%$. Nilai probabilitas $(\mathrm{Sig})$ hasil perhitungan SPSS adalah 0.242 . Nilai probabilitas ini lebih $0.05, \mathrm{H}_{0}$ ditolak. Ini berarti bahwa data yang diperoleh adalah berdistribusi normal.

Uji selanjutnya adalah uji homogenitas. Hasil uji homogenitas terlihat pada Gambar 3 berikut ini.

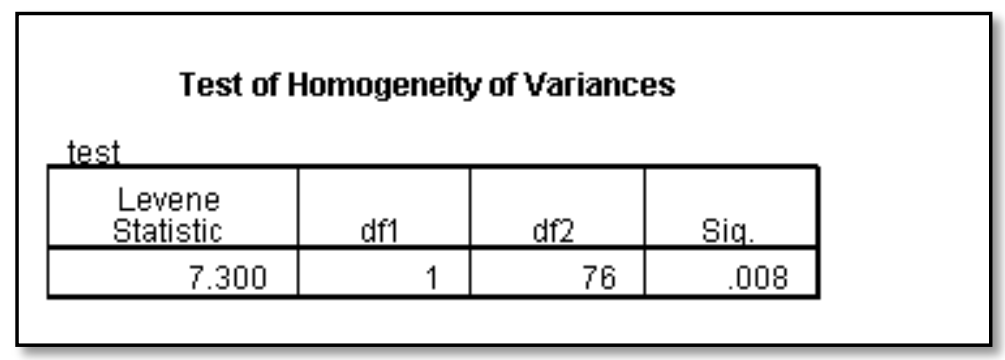

Gambar 3. Hasil Uji Homogenitas 
Pernyataan $\mathrm{H}_{0}$, varian dari kelompok pretest dan posttest tidak homogen. Pernyataan $\mathrm{H}_{1}$, varian dari kelompok pretest dan posttest homogen. Level of significance $(\alpha)$ pada uji homogen ini adalah 5\%. Dasar pengambilan keputusan adalah tolak $\mathrm{H}_{0}$ jika nilai probabilitas $(\mathrm{Sig})>5 \%$ dan terima $\mathrm{H}_{0}$ jika nilai probabilitas (Sig) < 5\%. Nilai probabilitas (Sig.) adalah 0.008. Nilai probabilitas ini kurang dari 0.05 , maka $\mathrm{H}_{0}$ diterima. Ini berarti bahwa varian dari kelompok pretest dan posttest tidak homogen.

Dari dua uji tersebut, data dikatakan normal dan tidak homogen. Oleh karena itu, selanjutkan dilakukan Uji Wilcoxon. Hasil dari uji tersebut ditampilkan pada Gambar 4.

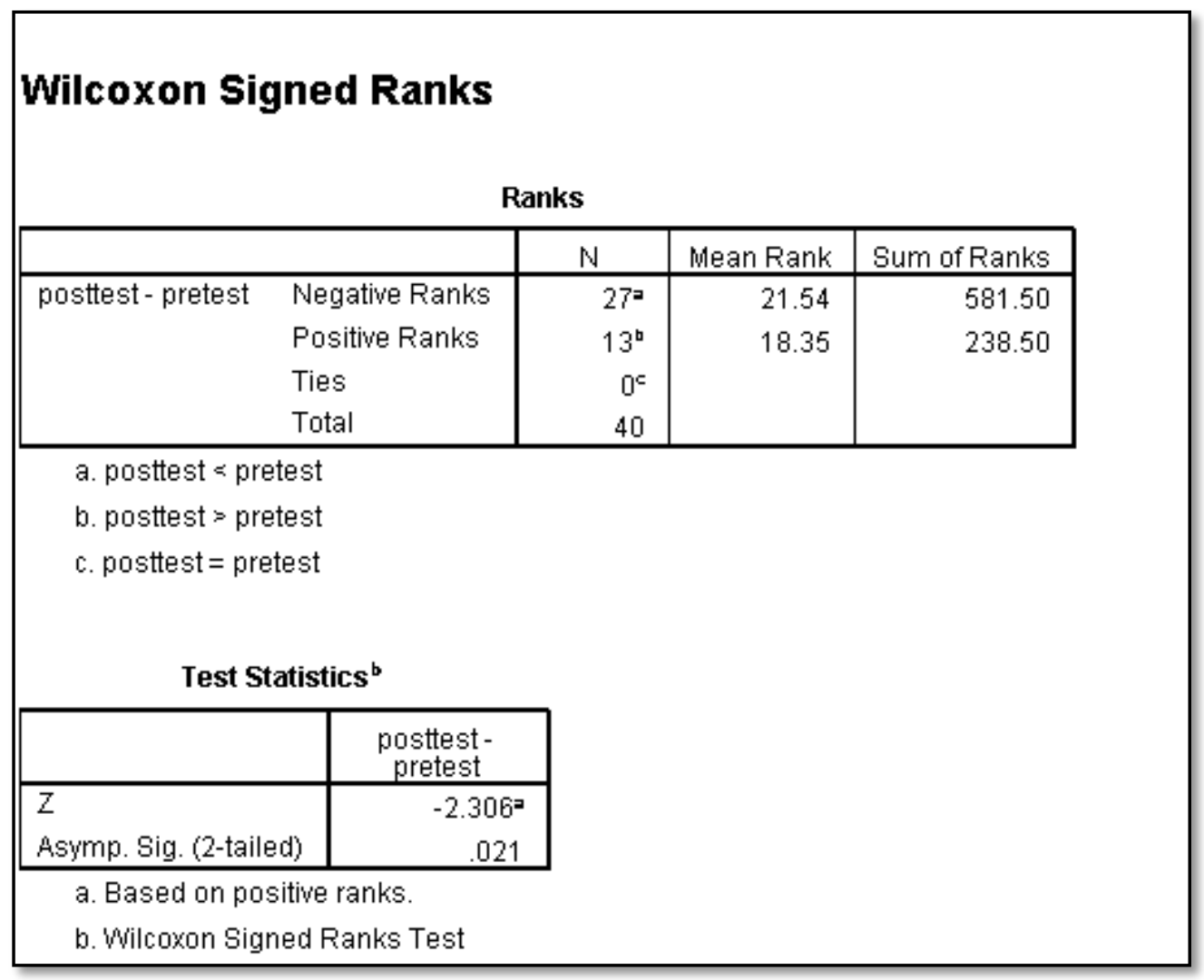

Gambar 4. Hasil Uji Wilcoxon

Pernyataan $\mathrm{H}_{0}$, tidak dapat perbedaan hasil belajar setelah dilakukan pembelajaran blended. Pernyataan $\mathrm{H}_{1}$, terdapat perbedaan hasil belajar setelah dilakukan pembelajaran blended. Level of significance $(\alpha)$ pada uji wilcoxon ini adalah $5 \%$. Dasar pengambilan keputusan adalah tolak $\mathrm{H}_{0}$ jika nilai probabilitas(Sig) $<5 \%$ dan terima $\mathrm{H}_{0}$ jika nilai probabilitas(Sig) $>5 \%$. Nilai Probabilitas (Sig.) adalah 
0.021. Nilai ini kurang dari 0.05 , maka $\mathrm{H}_{0}$ ditolak. Sehingga terjadi perbedaan antara hasil belajarsetelah dilakukan pembelajaran blended. Dengan kata lain, pembelajaran blended berpengaruh signifikan terhadap hasil belajar pada tingkat kepercayaan 95\%. Ini sesuai dengan hasil penelitian Pathoni dan Aminoto (2014), Arnesi dan Hamid (2015), dan Santoso (2009) yang hasil penelitian pembelajaran dengan online dapat meningkatkan hasil belajar.

Hasil pengolahan data dari kevalidanmodel sistem pembelajaran blended matematika diskrit adalah valid dengan nilai 3,58. Model sistem pembelajaran blended matematika diskrit dikatakan praktis dengan nilai 3. Model sistem pembelajaran blended matematika diskrit dikatakan hampir efektif bagi mahasiswa dengan nilai rata-rata 2.9 dari seluruh indikator.

\section{SIMPULAN}

Hasil pengolahan data dari pretest dan posttest pada mahasiswa yang menempuh mata kuliah Matematika Diskrit berdistribusi normal dan tidak homogen. Sehingga dilakukan uji Wilcoxon. Hasil dari uji tersebut adalah terjadi perbedaan antara hasil belajar setelah dilakukan pembelajaran blended. Dengan kata lain, pembelajaran blended berpengaruh signifikan terhadap hasil belajar pada tingkat kepercayaan $95 \%$.

Model sistem pembelajaran blended matematika diskrit dikatakan valid dengan nilai 3,58. Model sistem pembelajaran blended matematika diskrit dikatakan praktis dengan nilai 3. Berdasarkan angket yang dibagikan ke mahasiswa, model sistem pembelajaran blended matematika diskrit dikatakan hampir efektif bagi mahasiswa dengan nilai rata-rata 2.9 dari seluruh indikator.

\section{DAFTAR PUSTAKA}

Chaeruman, U. A. 2017. PEDATI model desain sistem pembelajaran blended. Jakarta: Ristekdikti.

Ghavifekr, S. \& Rosdy W.A.W. 2015. Teaching and learning with technology: Effectiveness of ICT Integration in School. International Journal of Research in Education and Science, Volume 1, Issue 2, Summer 2015. ISSN: 2148-9955

Hamid K, Abdul dan Arnesti, Novita. 2015. Penggunaan media Pembelajaran Online-Offline dan Komunikasi Interpersonal terhadap Hasil Belajar 
Bahasa Inggris. Jurnal teknik Informatika dan Komunikasi dalam Pendidikan, Vol. 2 No. 2, 16 Maret 2016, ISSN: 2407-7437.

Parta, I. N. 2009. Pengembangan Model Pembelajaran Inquiry untuk Penghalusan Pengetahuan Matematika Mahasiswa Calon Guru melalui Pengajuan Pertanyaan. Surabaya: Lembaga Penelitian Universitas Negeri Surabaya.

Pathoni, Hairul dan Aminoto, Tugiyo. 2014. Penerapan Media E-Learning Berbasis Schoology untuk Meningkatkan Aktivitas dan Hasil belajar Materi Usaha dan Energi di Kelas XI SMAN 10 Kota Jambi. Jurnal Sainmatika, Vol. 8, No. 1, Juni 2014, ISSN : 1979-0910.

Prasetyo, Iis. 2012. Teknik Analisa Data dalam Research and Development.dapat dilihat di http://staffnew.uny.ac.id/upload/132310875/pengabdian/teknikanalisis-data-dalam-research-and-development.pdf, diakses 24 Mei 2017.

Rusman, Kurniawan, D., \& Riyana, C. (2013). Pembelajaran Berbasis Teknologi Informasi dan Komunikasi: Mengembangkan Profesionalitas Guru. Jakarta: Rajawali Pers.

Santoso, E. 2009. Pengaruh pembelajaran online terhadap prestasi belajar kimia ditinjau dari kemampuan awal siswa. Tesis. Tidak dipublikasikan. Surakarta: PPs. Universitas Sebelas Maret. 